\title{
Article \\ Comparison between Concentrated Solar Power and Gas-Based Generation in Terms of Economic and Flexibility-Related Aspects in Chile
}

\author{
Catalina Hernández Moris ${ }^{1}{ }^{\mathbb{C}}$, Maria Teresa Cerda Guevara ${ }^{1, *} \mathbb{\infty}$, Alois Salmon ${ }^{1} \mathbb{D}$ and Alvaro Lorca ${ }^{2}$ \\ 1 Fraunhofer Chile Research Foundation, Santiago 7820436, Chile; catalina.hernandez@fraunhofer.cl (C.H.M.); \\ alois.salmon@fraunhofer.cl (A.S.) \\ 2 Department of Electrical Engineering, Department of Industrial and Systems Engineering, UC Energy \\ Research Center, Pontificia Universidad Católica de Chile, Santiago 7820436, Chile; alvarolorca@uc.cl \\ * Correspondence: maria.cerda@fraunhofer.cl
}

check for

updates

Citation: Hernández Moris, C.; Cerda Guevara, M.T.; Salmon, A.; Lorca, Á.G. Comparison between Concentrated Solar Power and Gas-Based Generation in Terms of Economic and Flexibility-Related Aspects in Chile. Energies 2021, 14 , 1063. https://doi.org/10.3390/ en14041063

Academic Editor: Antonio Rosato

Received: 12 January 2021

Accepted: 6 February 2021

Published: 18 February 2021

Publisher's Note: MDPI stays neutral with regard to jurisdictional claims in published maps and institutional affiliations.

Copyright: (c) 2021 by the authors. Licensee MDPI, Basel, Switzerland. This article is an open access article distributed under the terms and conditions of the Creative Commons Attribution (CC BY) license (https:// creativecommons.org/licenses/by/ $4.0 /)$.

\begin{abstract}
The energy sector in Chile demands a significant increase in renewable energy sources in the near future, and concentrated solar power (CSP) technologies are becoming increasingly competitive as compared to natural gas plants. Motivated by this, this paper presents a comparison between solar technologies such as hybrid plants and natural gas-based thermal technologies, as both technologies share several characteristics that are comparable and beneficial for the power grid. This comparison is made from an economic point of view using the Levelized Cost of Energy (LCOE) metric and in terms of the systemic benefits related to flexibility, which is very much required due to the current decarbonization scenario of Chile's energy matrix. The results show that the LCOE of the four hybrid plant models studied is lower than the LCOE of the gas plant. A solar hybrid plant configuration composed of a photovoltaic and solar tower plant (STP) with $13 \mathrm{~h}$ of storage and without generation restrictions has an LCOE 53 USD/MWh, while the natural gas technology evaluated with an $85 \%$ plant factor and a variable fuel cost of 2.0 USD/MMBtu has an LCOE of 86 USD/MWh. Thus, solar hybrid plants under a particular set of conditions are shown to be more cost-effective than their closest competitor for the Chilean grid while still providing significant dispatchability and flexibility.
\end{abstract}

Keywords: ancillary services; Concentrated Solar Power; natural gas industry; power industry; renewable energy sources; solar energy

\section{Introduction}

Chile is known worldwide for having privileged characteristics due to its high solar resource throughout the year in northern Chile, exceeding $3000 \mathrm{kWh} / \mathrm{m}^{2}$ per year in its direct normal irradiation component (SolarGIS @ 2021 World Bank Group, Bretton Woods, $\mathrm{NH}, \mathrm{USA}$ ) [1,2]. Chile currently has three independent electrical systems; these are the National Electrical System (SEN), the Aysén Electrical System (SEA), and the Magallanes Electrical System (SEM). In June 2020, at the national level, there was an installed capacity of $24.3 \mathrm{GW}$, where the SEN represented $99.31 \%$ of the installed capacity at the national level, compared to the other two smaller systems, which represented $0.25 \%$ and $0.44 \%$, respectively [3]. Although an important part of the installed capacity of the SEN is made up of technologies based on renewable resources, currently, $51.1 \%$ of the grid is still based on traditional thermal energy, which emits polluting gases into the environment, see Table 1. Chile is committed to reducing the associated emissions in the coming years $[4,5]$.

The energy sector in Chile is the main greenhouse gas emitting sector, with a $69.6 \%$ share in 2013. The Energy Industry subcategory composed of electricity generation is the most important with $45.3 \%$ contribution in the same year [6]. In general, the gross consumption of primary energy in Chile is based on fossil fuels; in 2013, natural gas represented $12.8 \%$ of total consumption despite the fact that $80.1 \%$ of supplies were imported 
and its main use was for electricity generation, in which only $5.5 \%$ was attributed to other renewable energies including hydroelectric, wind, solar and biogas [6].

Table 1. Detail of installed capacity and electricity generation for the year 2019 in the National Electrical System (SEN). Percentages in parentheses [3,7].

\begin{tabular}{ccc}
\hline Technology Type & Installed Capacity (MW) & Generated Energy 2019 (GWh) \\
\hline \multirow{2}{*}{ Hydroelectric Dam } & 3421.53 & 9199.12 \\
& $14.20 \%$ & $12.0 \%$ \\
Run-of-river hydropower & 3301.00 & $11,631.07$ \\
Solar Photovoltaic & $13.7 \%$ & $15.1 \%$ \\
& 2750.41 & 6382.91 \\
Wind & $11.4 \%$ & $8.3 \%$ \\
& 1792.08 & 4818.10 \\
Biomass & $7.4 \%$ & $6.3 \%$ \\
& 501.41 & 1822.46 \\
Geothermal & $2.1 \%$ & $2.4 \%$ \\
& 39.70 & 201.64 \\
Total Renewable & $0.2 \%$ & $0.3 \%$ \\
\hline \multirow{2}{*}{ Coal } & $\mathbf{1 1 , 8 0 6 . 1 3} \%$ & $\mathbf{3 3 , 8 4 1 . 7 9}$ \\
& $\mathbf{4 8 . 9} \%$ & $\mathbf{4 3 . 3} \%$ \\
\hline Natural Gas & 4774.94 & $28,390.26$ \\
Diesel Oil & $19.8 \%$ & $36.9 \%$ \\
& 4381.53 & $14,130.97$ \\
Total Conventional & $18.2 \%$ & $18.4 \%$ \\
& 3161.61 & 290.73 \\
\hline \multirow{2}{*}{ Total SEN } & $13.1 \%$ & $0.4 \%$ \\
\hline
\end{tabular}

Chile has taken on the challenge of the 2015 Paris climate agreement by committing to reduce Greenhouse Gas (GHG) emissions by $30 \%$ per unit of gross domestic product by 2030 compared to 2007. Thus, different sectors must be part of this challenge, even more so the energy sector, which represents $78 \%$ of total GHG emissions [8].

The Ministry of Energy, in its 2018-2022 RoadMap, raises the issue of energy grid decarbonization with a proposed schedule for the withdrawal or conversion of coal-fired power plants. The purpose is to analyze the effect on supply security and economic efficiency of the National Electric System, as well as the local economic activity and its technological and environmental impacts [4]. In this same document, it is stated that new coal-fired projects that do not have a carbon capture and storage system or other equivalent technologies will not be developed. For this reason, the new electricity generation projects to be promoted within Chile must consider a series of restrictions to meet environmental goals and be competitive within the Chilean electricity market.

Despite the fact that Chile has privileged characteristics to promote solar technologies, concentrated solar power (CSP) technology with storage is only recently emerging in the Chilean energy grid.

CSP technology with storage corresponds to a form of generation of clean electrical energy that provides different systemic benefits as it allows for the production of dispatchable energy, increases the capacity factor, and provides flexibility to the network, in addition to allowing integration in greater proportions of variable renewable energy in power systems.

The foregoing raises the concern of studying the competitiveness between CSP technology and traditional thermal power plants based on natural gas within the National Electricity Market from two points of view: the first in economic terms based on the Lev- 
elized Cost of Energy (LCOE) and second, in terms of the systemic benefits related to the flexibility of both technologies.

The LCOE represents the current total cost of building and operating a power plant [9-11], therefore, it considers all costs (Capital expenditures (CAPEX) and Operational expenditures (OPEX)) throughout its useful life and the generation of energy as shown in Equation $(1)[12,13]$. For the calculation of the LCOE of solar technologies, the energy generation is used as an input and calculated in the system advisor model (SAM) [14].

$$
\mathrm{LCOE}=\frac{\text { CAPEX }+\sum_{\mathrm{i}=1}^{\mathrm{N}} \frac{\text { OPEX }_{\mathrm{i}}}{(1+\mathrm{t})^{\mathrm{i}}}}{\sum_{\mathrm{i}=1}^{\mathrm{N}} \frac{\text { Production }_{\mathrm{i}}}{(1+\mathrm{t})^{\mathrm{i}}}}
$$

This work compares the economic point of view based on the LCOE-between hybrid plants (CSP + PV) and gas plants, also analyzing the benefits that each technology contributes to the Chilean electricity system. Accordingly, the remainder of the paper is organized as follows. Section 2 provides a description of CSP technology. Section 3 presents the description of gas technology. Section 4 compares these technologies from the economic point of view using the LCOE metric, analyzing different configurations of the CSP plant for the hybrid plant. Finally, Section 5 presents a discussion of the results and the different attributes of the technologies, followed by the conclusions in Section 6 .

\section{CSP Technology}

Concentrated solar power (CSP) uses mirrors to concentrate the sun's energy in a receiver to warm up a heat transfer fluid that, through a thermal process, generates steam to drive a turbine and thus generate electrical energy. These plants can use molten salt thermal storage systems to give flexibility to the electrical grid, avoiding fluctuations in supply and maintaining continuous production [15]. There are four types of CSP systems that are categorized in two ways according to the type of receiver; as per Figure 1, point or linear receivers.

Systems with a linear receiver work in temperature ranges between 300 and $450{ }^{\circ} \mathrm{C}$, they use sun-tracking on a single axis (from East to West) to concentrate sunlight on the receiver during daylight hours. The heat transfer fluid can be water or thermal oil, and the use of solar salt systems to reach temperatures of up to $550{ }^{\circ} \mathrm{C}$ is being studied. On the other hand, systems with a single point receiver reach a temperature ranging between $250-560{ }^{\circ} \mathrm{C}$, and due to their construction, must use systems with two-axis tracking, and the heat transfer fluid are typically solar salt (sodium and potassium nitrate) and/or water/steam [16].

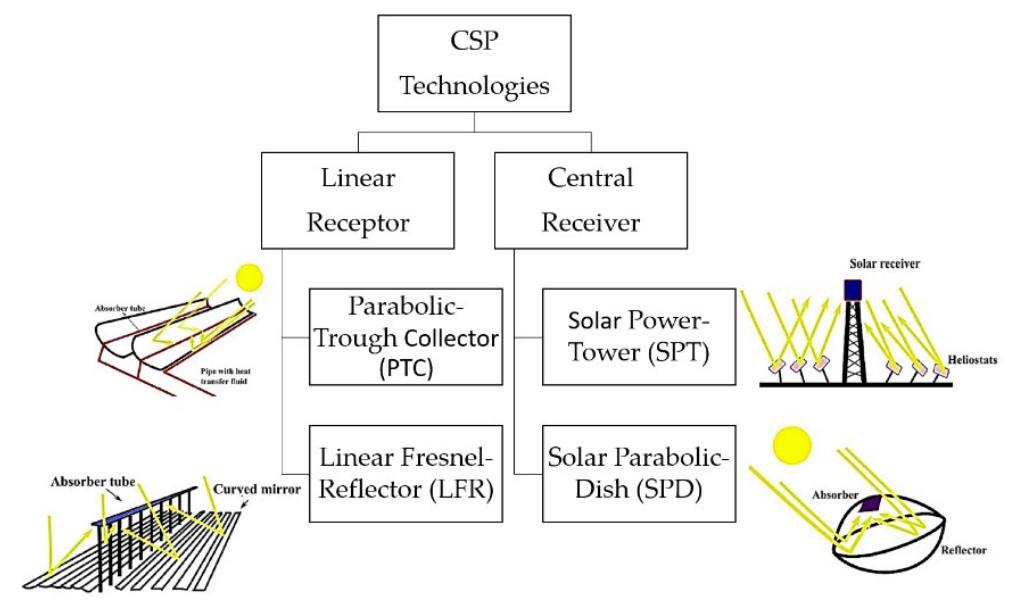

Figure 1. Classification of existing concentrated solar power (CSP) technologies. Source of the images [17]. 
The main differences between tower technology and the rest of the CSP technologies are highlighted below:

- Tower systems reach higher temperatures in the receiver and therefore in storage,

- The annual energy production regime is more homogeneous, that is, the production difference does not show great differences depending on the time of year,

- Construction of the heliostat field does not require exhaustive preparation; it can even be built on land with a slight inclination [18,19].

Table 2 below presents a comparative table from the technical point of view of the different types of CSP technologies.

Table 2. Comparative table of technical parameters of CSP technologies [16,20].

\begin{tabular}{|c|c|c|c|c|}
\hline Items & PTC & LFR & SPT & SPD \\
\hline Capacity, MWe & 10-200 & 10-200 & 10-150 & $0.01-0.4$ \\
\hline $\begin{array}{c}\text { Operating } \\
\text { temperature range, } \\
{ }^{\circ} \mathrm{C}\end{array}$ & $150-400$ & $150-400$ & $300-1200$ & $300-1500$ \\
\hline $\begin{array}{l}\text { Annual efficiency } \\
\text { from solar to } \\
\text { electricity, } \%\end{array}$ & 15 & $8-10$ & $20-35$ & $20-35$ \\
\hline $\begin{array}{l}\text { Required area, } \\
\mathrm{m}^{2} / \mathrm{MWh}\end{array}$ & $4-6$ & $6-8$ & $8-12$ & $30-40$ \\
\hline $\begin{array}{l}\text { Maximum efficiency } \\
\text { of the plant, } \%\end{array}$ & $14-20$ & $\sim 18$ & $23-45$ & $\sim 30$ \\
\hline $\begin{array}{l}\text { Water requirement, } \\
\mathrm{m}^{3} / \mathrm{MWh}\end{array}$ & $\begin{array}{c}3 \\
\text { (wet cooling) } \\
0.3 \\
\text { (dry cooling) } \\
0.4-1.7 \\
\text { (hybrid) }\end{array}$ & $\begin{array}{c}3 \\
\text { (wet cooling) } \\
0.2 \\
\text { (dry cooling) }\end{array}$ & $\begin{array}{c}2-3 \\
\text { (wet cooling) } \\
0.25 \\
\text { (dry cooling) } \\
0.1-1 \\
\text { (hybrid) }\end{array}$ & $\begin{array}{l}0.05-1 \\
\text { (For cleaning } \\
\text { mirrors) }\end{array}$ \\
\hline $\begin{array}{l}\text { Molten salt } \\
\text { storage }\end{array}$ & $\begin{array}{l}\text { Commercially } \\
\text { available }\end{array}$ & $\begin{array}{l}\text { Possible but not } \\
\text { proven }\end{array}$ & $\begin{array}{l}\text { Commercially } \\
\text { available }\end{array}$ & $\begin{array}{l}\text { Possible but } \\
\text { not proven }\end{array}$ \\
\hline $\begin{array}{c}\text { Steam conditions, } \\
{ }^{\circ} \mathrm{C} / \mathrm{bar}\end{array}$ & 380 to $540 / 100$ & $260 / 50$ & $540 / 100$ to 160 & Does not apply \\
\hline
\end{tabular}

\subsection{Environmental Benefits from CSP Technology}

The use of renewable energy with storage promises to be one of the most viable alternatives to highly polluting fossil fuel power plants [21]. One megawatt of installed CSP avoids the emission of 688 tons of $\mathrm{CO}_{2}$ compared to a combined cycle system and 1360 tons of $\mathrm{CO}_{2}$ compared to a coal cycle (steam cycle) power plant, as shown by $[19,22]$.

\subsection{CSP Operation}

CSP plants, see Figure 2, have been widely studied worldwide and are distinguished from other renewable technologies by providing energy, power, and ancillary services to the electrical market, an attribute that not all technologies have within their marketing schemes. CSP technology has various particular characteristics, such as being clean energy, without greenhouse gas emissions, or particulate matter as a traditional thermal power plant would be. Among its economic characteristics, it has a low variable generation cost, a high plant factor depending on the design and a high sufficiency power, giving the system robustness. Among the complementary services, CSP plants have the characteristic of managing their inter-hourly operation at low operating costs, fast start-up and operation times, rotating machine inertia, primary and secondary frequency control, as well as voltage control [23]. 


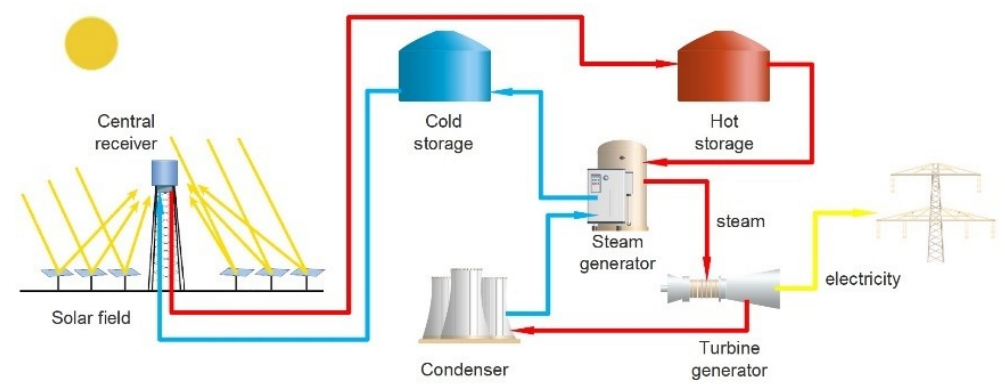

Figure 2. Schematic of a tower CSP generation system.

The operation of tower CSP plants depends on multiple factors such as the level of direct normal irradiation of the previous day and the forecast of the following day, the duration of day and night, the operation of the previous day, the instantaneous temperature of the ponds and the operation requirement of the moment or the next day [23]. However, the transitory effects of the solar resource do not influence the generation of thermal energy since the system of molten salts and pipes provides thermal inertia to the system [24]. The plant operator can manage the extraction of heat from the salts by controlling the flow in the exchanger and thus, the operation of the power block [23]. Regretfully, information on the control of the operation of these systems is difficult to obtain since there are few plants operating successfully worldwide and access to information is limited [24].

Despite the above, in the reference [23], it is proposed that for winter days (less solar resource and longer duration of the night), the operator can manage the plant to operate at lower power and return the salts to the cold tank at 2 or $3^{\circ} \mathrm{C}$ above the nominal temperature in order to connect the thermal storage discharge with the start in the morning and thus ensure a quick start the next day. Another study is the one carried out by Zurita et al. [24] that studies the performance of the receiver operation of a tower CSP plant based on sub-hourly simulations in order to incorporate the effects of solar resource variability in a hybrid plant composed of a $100 \mathrm{MW}$ tower CSP plant with $14 \mathrm{~h}$ of storage and a solar multiple of 2 for three days with a varying solar resource profile. Specifically for a simulated day with a low solar resource (continuous intermittence during the day of the DNI profile) and resolution of $1 \mathrm{~min}$ (more realistic operating parameter), the tower receiver does not operate because the minimum conditions established by the control are not met. Additionally, the hot tank is not loaded or unloaded because it is at a minimum level and the receiver does not work to heat the molten salts during a day with high solar variability. Therefore, the generation of a CSP plant depends on the mode of operation and the probability of days with low radiation level and/or high variability in consecutive days, a very rare situation in northern Chile where more than $90 \%$ of days are under clear sky conditions $[25,26]$.

\section{Gas Technology}

In Chile, there are two types of electric power generation technologies that use natural gas, thermoelectric with open or simple cycle turbines (TG CA) and thermoelectric with natural gas turbines (TG), steam turbine (TV) with boiler heat recovery steam generator (HRSG) in combined cycle (CC) configuration [27].

Gas turbines in an open cycle and combined cycle (TG CA and TG CC) use the highpressure combustion gases to move a turbine coupled to an electric generator, which is known as the Brayton cycle. On the other hand, the steam turbine (TV) of combined cycle plants uses the thermodynamic water-steam cycle. The fuel burned in the boiler heats water and transforms it into high-pressure steam, which drives the turbine coupled to the electric generator. The steam that comes out of the turbine reaches a condenser to convert it into water again and thus return it to the boiler to restart the steam production cycle.

Combined cycle plants, as shown in Figure 3, use the TG CA and TV cycles to recover the energy contained in the exhaust gases of the TG CA and thus increase the total efficiency of the system. In this way, the hot air that comes out of the gas turbine that has a high 
energy content is captured and directed to the heating of water and the generation of steam in boilers or heat exchangers that supply the steam turbine (TV). This is known as a heat recovery boiler (HRSG) $[27,28]$.

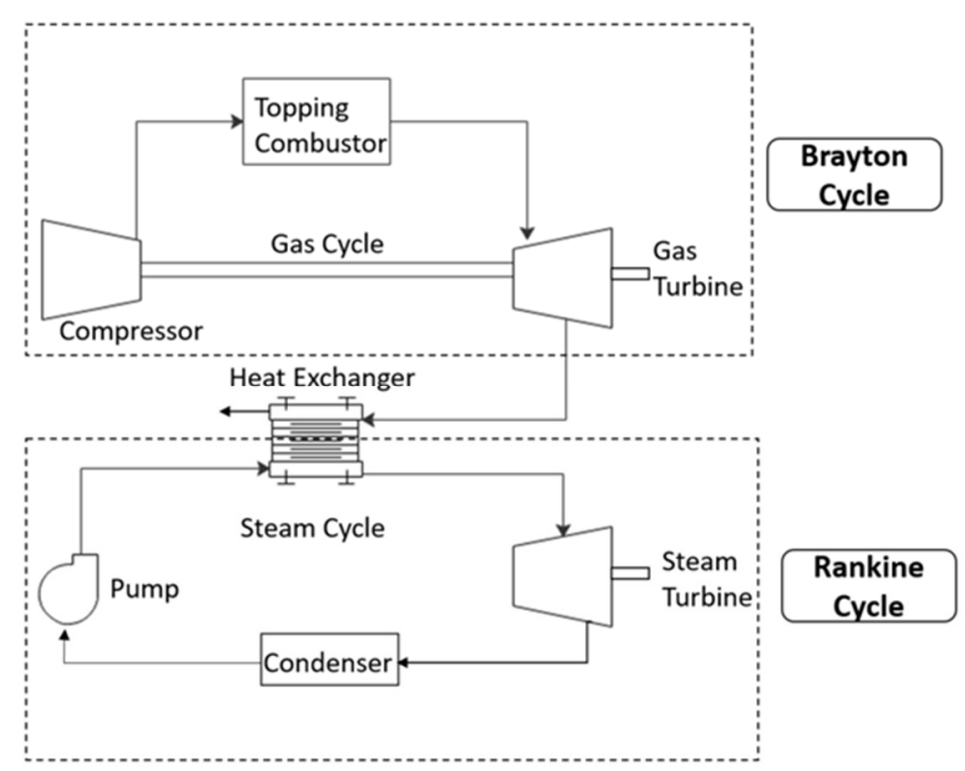

Figure 3. Scheme of a combined cycle power plant. A Brayton cycle is shown above, and the cycle below corresponds to a Rankine Cycle.

In general, the advantage of combined cycles within the national electricity grid is due to the technical characteristics of the technology. One quality is its rapid start-up in the open cycle and later in the combined cycle, which makes it an ideal plant to form part of the support of renewable energies from variable sources, providing flexibility to the grid. Other advantageous characteristics are the high efficiency of the cycle, the ability to give peak power, and function as frequency regulators in order to give stability to the system. However, it should not be forgotten that these types of plants use fossil fuels. Natural gas is the ideal fuel for gas turbines; however, by modifying some components, this type of power plant can use other types of fuels such as light oil, liquefied petroleum gas, or even previously treated pulverized coal, which are more expensive fuels, more polluting and with lower calorific value.

\subsection{Environmental Impacts of Gas Generation}

Gas technology, like other traditional technologies, impacts climate change by burning fossil fuels, with the difference that natural gas emits fewer pollutants than other fuels. Natural gas is mainly composed of methane, which is a greenhouse gas 20 times more harmful than $\mathrm{CO}_{2}$ in the short term, with immediate effects that will raise temperatures for decades to come [29].

On the other hand, the extraction of natural gas turns it into a dangerous gas with noxious health effects. Extraction workers require specialized personal protective equipment, and it is suspected that the chemicals necessary for the fracking process potentially contaminate the water table in populated areas [30,31].

Combined cycle plants have lower emission rates compared to other conventional thermal plants, due to the heat recovery cycle that they use to generate steam with the hot exhaust gases of the gas turbine. Despite the above, within the Chilean energy sector, gas represents $14 \%$ of $\mathrm{CO}_{2}$ emissions [32] compared to the rest of fuels, as shown in Figure 4. 


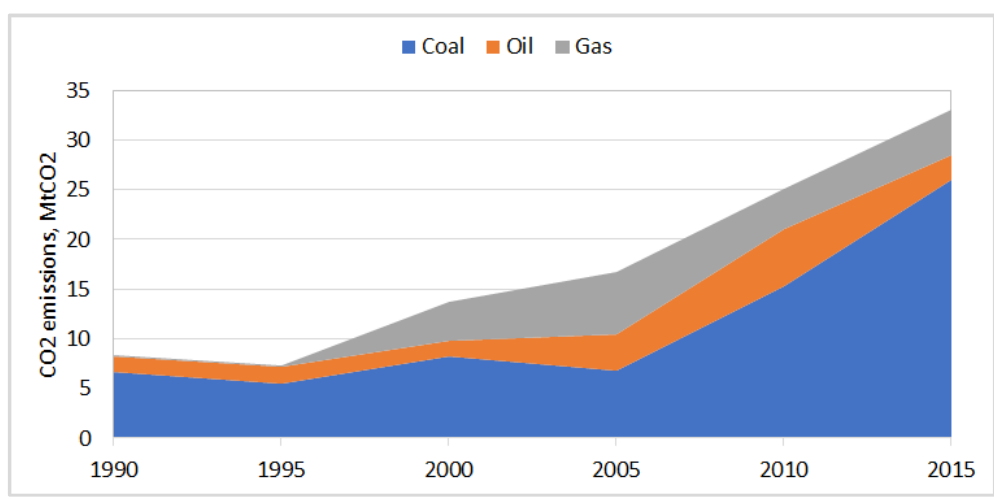

Figure 4. $\mathrm{CO}_{2}$ emissions from electricity and heat by energy source-Chile [32].

Natural gas is roughly $65 \%$ to $95 \%$ methane by volume and contains some other gases such as ethane and propane in lower concentrations and has one of the highest calorific powers of the family of fuels, whether gaseous or liquid. However, unlike coal or oil, it contains very little sulfur, making it a cleaner fuel, and produces less $\mathrm{CO}$ as it presents better combustion properties compared to other fossil fuels. This makes natural gas a favorable fuel, as turbine technical specifications consider greenhouse gas generation rates, and it is essential that these comply with the existing regulations in each country to allow their operation.

\subsection{Gas Technology Operation}

Within the framework of the agreements to reduce polluting emissions, Chile has committed to the closure of coal-fired generating plants by 2040 and promoted Law $\# 20,780$ that incorporates a green tax, whose purpose is to reduce both global and local pollution by establishing a cost for polluting, seeking in turn to generate a change in behavior in those responsible for polluting emissions (carbon and other harmful gases).

Green taxes are based on the principle of "whoever pollutes pays" and economic efficiency, since they allow compensating society for the costs generated by polluting facilities and at the same time an incentive for companies to reduce their emissions. Currently, Article 8 of Law \#20,780 establishes an "annual tax for fiscal benefit that will tax the emissions into the air of particulate matter $(\mathrm{PM})$, nitrogen oxides $\left(\mathrm{NO}_{\mathrm{x}}\right)$, sulfur dioxide $\left(\mathrm{SO}_{2}\right)$, and carbon dioxide $\left(\mathrm{CO}_{2}\right)$, produced by establishments whose emission sources, individually or as a whole, emit 100 or more annual tons of PM, or 25,000 or more annual tons of $\mathrm{CO}_{2}{ }^{\prime \prime}$ (as translated from Spanish by the authors). The tax for emissions of particulate material, nitrogen oxides, and sulfur dioxide for fixed sources is calculated considering the population size and the air quality of the commune where the affected establishment is located. Currently, the per-capita costs for each pollutant are shown in Table 3. At these values, an extra weighing factor of 1.1 should be considered for areas declared as latent and 1.2 if the area has been declared as saturated [33].

Table 3. Per capita costs of one ton per pollutant. $\left.{ }^{*}\right)$ The exception of the tax on $\mathrm{CO}_{2}$ emissions in the case of fixed sources whose primary energy source is biomass [33].

\begin{tabular}{cc}
\hline Pollutant & Per Capita Cost, USD \\
\hline Particulate Material $(\mathrm{PM})$ & 0.9 \\
Nitrogen Oxides $\left(\mathrm{NO}_{\mathbf{x}}\right)$ & 0.01 \\
Sulfur Dioxide $\left(\mathrm{SO}_{2}\right)$ & 0.025 \\
Carbon Dioxide $\left(\mathrm{CO}_{2}\right)\left(^{*}\right)$ & 5 \\
\hline
\end{tabular}

The green tax adopted in Chile is a downstream tax (it does not tax the carbon content of fuels used in production processes), so the objective is distorted [34]. This is because the tax is not incorporated into the production cost of the energy that determines its dispatch 
in the Chilean electric system and because part of the tax charge is transferred to nonpolluting emission sources [35]. This is explained in article 8 of Law 20,780: "The tax should not be considered when determining the instantaneous marginal cost of energy when it affects the marginal generation unit of the system. However, for units whose total unit cost-being the variable cost considered in the dispatch plus the unit value of the tax-is greater than or equal to the marginal cost, the difference between the valuation of their injections at marginal cost and at said cost the total unit must be paid by all electricity companies that make withdrawals of energy from the system, in proportion to their withdrawals" (as translated from Spanish by the authors). In other words, if the generating unit that determines the marginal cost must pay the green tax and its total costs exceed the marginal cost, the difference is passed on to the other generating units that withdraw energy from the system, whether clean or not. Therefore, the tax does not tax $100 \%$ of $\mathrm{CO}_{2}$ emissions to emitting sources, as it is being offset by all generating units including clean technologies [33]. Additionally, there may be a double compensation payment in the case of energy supply contracts in the clauses of transfers (pass through) of costs associated with the supply of electricity (payment by generators and also receiving payment by customers).

In the case of natural gas plants, one of the parameters that determine their operation in the national electricity grid is the cost of the input, so it is relevant to examine the projected cost of natural gas for the coming years. The preliminary technical report on short-term node pricing carried out by the National Energy Commission (CNE) in June 2020 shows that the price of natural gas should remain stable until 2024, corresponding to fuel costs informed by system operators. As of January 2025, the projection made by the $\mathrm{CNE}$ is used, which for the open cycle and combined cycle plants with regasified natural gas consider an additional cost component of 0.12 USD/MMBtu added to the projected prices of liquefied natural gas (LNG) due to the cost of regasification [36]. Figure 5 shows the LNG projection result published in this report.

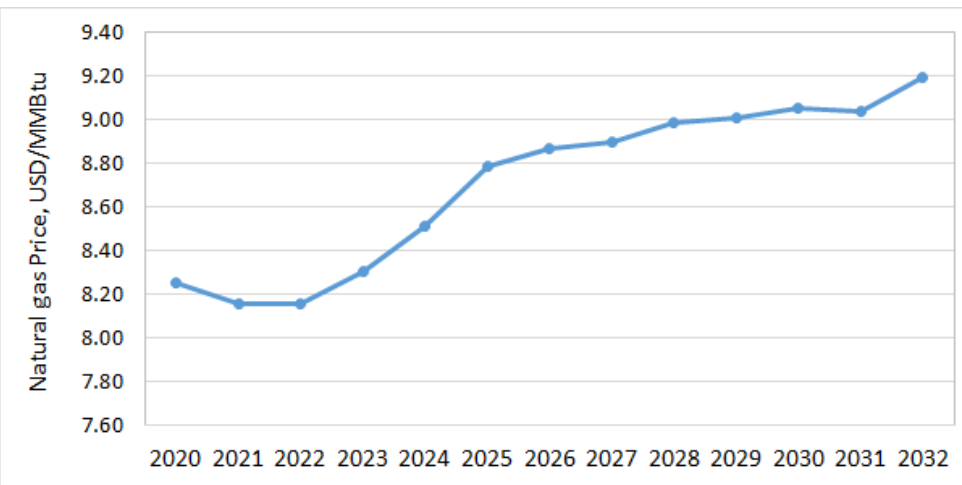

Figure 5. Liquefied natural gas (LNG) Price projection [36].

In the same vein, it is interesting to observe the trend of the spot price of natural gas as it is the main input for the generation of gas-based thermoelectric plants. Henry Hub Natural Gas is a grade of natural gas that is produced in Erath, Louisiana, where the price of this input in the United States is determined by exchange and strongly related to the economic principle of supply/demand, in addition to dynamic conditions such as production profiles, weather conditions and, to a lesser extent, oil prices [37]. The Henry Hub is a highly liquid trading point, which also represents a delivery standard for NYMEX natural gas futures contracts in the United States. The purchase and sale operations began in April 1990 and it is sold 18 months in advance, for this reason, it is used as one of the main financial hedging tools in the market [38]. Figure 6 shows the price of natural gas in recent times [39], from July 2019 to June 2020, while Figure 7 shows the historical variation of the price of natural gas with respect to the previous day during the last 20 years, which has had high volatility [40]. 


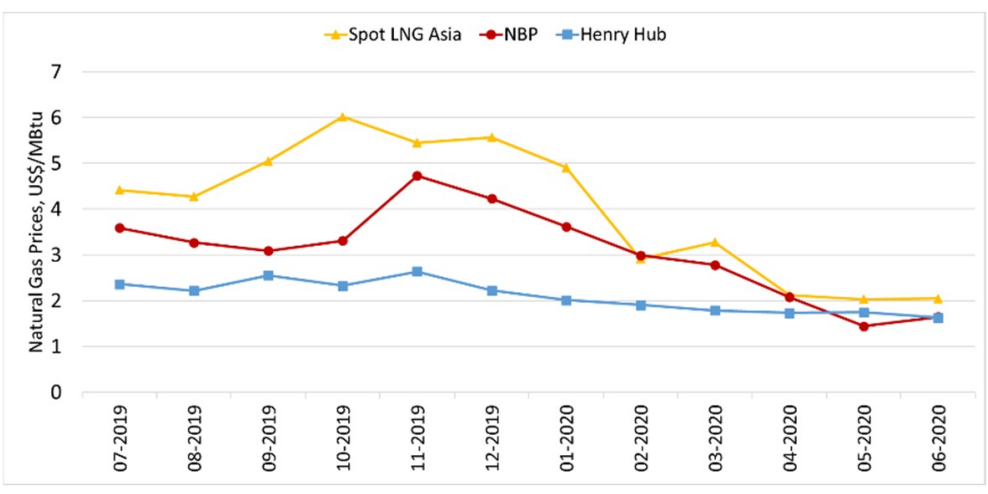

Figure 6. Daily variation of the price of natural gas [39].

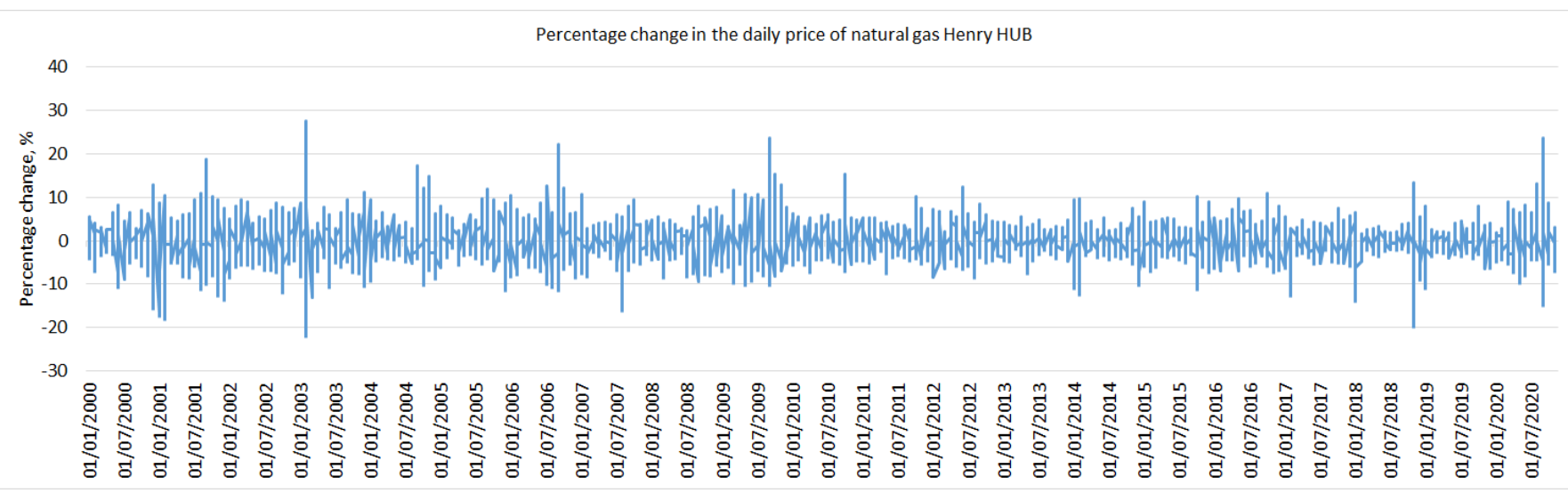

Figure 7. Percentage reference of the variation of the daily price of natural gas Henry HUB [40].

\section{Economic Comparison between Hybrid CSP+PV Plant and Natural Gas Plant}

\subsection{Solar Energy}

The case to be studied below is a $13 \mathrm{~h}$ storage solar tower plant (STP) plant next to a photovoltaic plant installed in Tierra Amarilla in the Atacama Region, $16 \mathrm{~km}$ away from the $110 \mathrm{kV}$ Los Loros Substation. The site was selected according to the study carried out by Hernández et al. [41] for a CSP plant with the characteristics considered. Table 4 shows the radiation characteristics of the best location for the CSP plant, that is, the locality with the lowest LCOE is around Copiapó (selected site) [42].

Table 4. Radiation characteristics for the study site (latitude: -27.7799, longitude: -69.974) [42].

\begin{tabular}{cccc}
\hline Energy & $\begin{array}{c}\text { Global Horizontal } \\
\text { Irradiance }\end{array}$ & $\begin{array}{c}\text { Direct Normal } \\
\text { Irradiance }\end{array}$ & $\begin{array}{c}\text { Diffuse Horizontal } \\
\text { Irradiance }\end{array}$ \\
\hline $\begin{array}{c}\text { Annual total energy, } \\
\mathrm{kWh} / \mathrm{m}^{2} \text {-year }\end{array}$ & 2544 & 3811 & 207 \\
$\begin{array}{c}\text { Annual average daily } \\
\text { total energy, } \mathrm{kWh} / \mathrm{m}^{2}\end{array}$ & 7.0 & 10.4 & 0.6 \\
\hline
\end{tabular}

For the above, the power generation of a photovoltaic plant will be simulated together with a CSP plant with different dispatch conditions using the software System Advisor Model [14], for which different configurations are analyzed as presented in Table 5 and which will be delved into later. This type of combination has been extensively studied in recent times due to the various comparative advantages to individual technologies [43]. For example, compared to purely photovoltaic systems, hybrid technology (CSP together with 
PV) produces better quality as CSP technology provides stability in the hybrid system. On the other hand, compared to purely CSP systems, the cost of energy production is reduced.

Table 5. Description of case studies.

\begin{tabular}{cc}
\hline Hybrid Case & Case Description \\
\hline Base & PV + CSP without restriction \\
Optimistic summer and winter flat profile & PV + Night CSP in winter \\
Summer restriction and optimistic winter & PV + CSP supplement PV in summer and \\
Flat Profile & without restriction in winter \\
& PV + Night CSP \\
\hline
\end{tabular}

Table 6 shows the technical simulation parameters of each of the plants that will be studied. In the case of the CSP plant, the base case studied in reference [41] is used, which follows the Copiapo Solar project presented in Chile by SolarReserve [44].

Table 6. Input design parameters for PV and STP plant [44].

\begin{tabular}{cccc}
\hline \multicolumn{1}{c}{ CSP Plant } & \multicolumn{2}{c}{ PV Plant } \\
\hline Solar Field & Value & Orientation and monitoring \\
\hline $\begin{array}{c}\text { Heliostat number } \\
\text { Surface area }\end{array}$ & $10,014.0$ & Arrangement type & Tracking on an axis \\
(W-E)
\end{tabular}

\subsubsection{Base Case}

The first case to study is one where the CSP plant does not have generation restrictions throughout the year and is thus able to generate in the daytime as well as in the night due to the high radiation conditions. Figure 8 shows in blue color the monthly generation of the CSP plant without restriction, and in orange, the PV plant throughout the year according to the design parameters indicated in Table 6. It can be seen that during the winter, the generation of energy decreases according to the decrease in the solar resource, also decreasing the energy stored during the day, making 24/7 generation impossible. However, having a CSP plant designed for the production of energy during the winter with a $24 / 7$ profile requires an oversized heliostat field, among other design conditions, increasing the investment costs. Additionally, an over-production would be generated in summertime. 


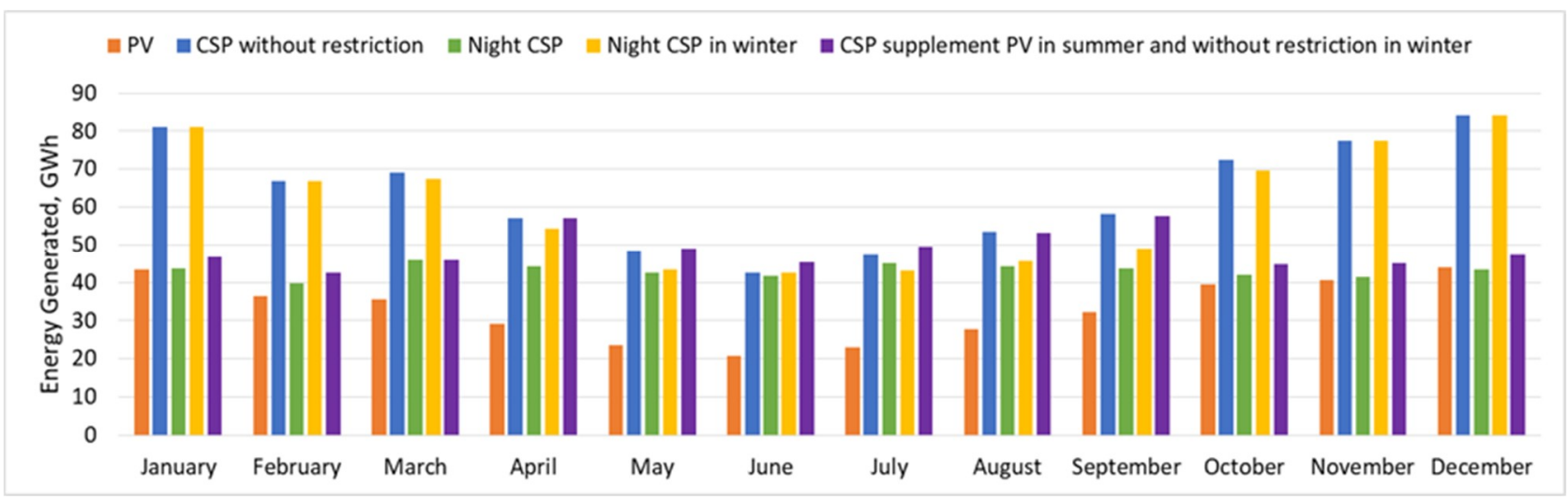

Figure 8. Annual energy generation for each plant according to the month of the year (CSP with $13 \mathrm{~h}$ of storage).

With this configuration, summer generation of the CSP plant throughout the day and throughout the night is possible, which allows the hybrid plant to reach a generation level during the day (7:00 a.m. to 7:00 p.m.) of $240 \mathrm{MWh}$ and at night a constant and equal generation at $130 \mathrm{MWh}$ from 8:00 p.m. to 6:00 a.m. During the winter, the generation of the PV plant decreases due to radiation conditions and the generation of the CSP plant also decreases, so that during the day the generation reaches levels of $200 \mathrm{MWh}$ and during the night $130 \mathrm{MWh}$. It should be mentioned that during the winter the energy stored by the CSP plant is not enough to generate during all hours of the night, managing only $6 \mathrm{~h}$.

\subsubsection{Optimistic Summer and Winter Flat Profile}

Another relevant case to examine is the generation of a hybrid plant consisting of a PV plant and a CSP plant without restrictions in the summer, as shown in yellow in Figure 8, whereas during the winter, restrictions are set in place to prioritize generation during the night. This way, in the summer, all the possible energy is generated, making the most of the radiation conditions, whereas during the winter, the generation of the day shifts the generation of the CSP plant to nighttime hours, maintaining a flat profile during winter. From Figure 8 , it is shown that the monthly energy generation is very similar to the base case (CSP without restriction and PV), where in the summer, the generation of the solar concentration unit is around $80 \mathrm{GWh}$ and during winter close to $40 \mathrm{GWh}$.

\subsubsection{Summer Restriction and Optimistic Winter}

Another configuration for a $13 \mathrm{~h}$ storage CSP plant involves the restriction of daytime operation in the summer (from October to March) due to possible energy curtailment caused by a high installation of photovoltaic plants in northern Chile, while the operation in winter (June and July) is unlimited. Additionally, for the months of April, May, August, and September, turbine operation is restricted to a factor of $50 \%$ to promote generation at night. For a CSP plant with $13 \mathrm{~h}$ of storage with this restriction, the solar multiple (SM) that optimizes the LCOE according to the SAM simulations is 1.7.

Figure 8 shows (in purple) the results of the monthly generation of CSP as a complement to the plant in summer and without restrictions in winter. Thus, the summer months correspond to the base case, while during the winter months, a generation of $40 \mathrm{GWh}$ is achieved, which corresponds to half that of summer.

\subsubsection{Flat Profile}

The last case is a hybrid plant made up of a CSP plant restricted to operation in nonsunny hours, complementing the generation of the PV plant. Using SAM, the generation of the CSP plant is limited from 8:00 p.m. to 8:00 a.m. for the whole year, depending on the month, based on the fraction of the turbine output so that it can better adapt to the generation of the PV plant. On the other hand, when limiting the generation capacity of the CSP plant, it is observed that the optimal solar multiple based on the real LCOE simulated 
by SAM for this type of operation is 1.5. The technical parameters of each plant correspond to the same ones used previously and described in Table 5.

It can be seen in Figure 8 that for this configuration (in green) the generation of the CSP plant at night is more constant throughout the year, reaching $130 \mathrm{MWh}$. During the day, it stores energy that is dispatched during the night, with a peak in July and minimum value in February, which corresponds to half the generation compared to the base case condition in the summer. The photovoltaic plant generates less energy during winter due to the decrease in solar resource.

\subsubsection{CSP with $6 \mathrm{~h}$ of Storage}

A CSP plant with $6 \mathrm{~h}$ of storage is simulated below under the same operating system scenarios indicated above. The solar multiple value was optimized for each of the cases based on the real LCOE obtained by SAM, see Table 7, as a cost grid for a plant with these characteristics for Chile was not identified. Figure 9 shows the monthly generation for the different plants according to the different configurations throughout the year. From the figure, it is observed that the generation of the year-restricted (in blue) CSP plant is a constant $20 \mathrm{GWh}$ year-round and reaches a third of the unrestricted generation value for the summer months, while in winter months, it generates during the day and $6 \mathrm{~h}$ at night due to the lower amount of storage hours.

Table 7. Description of case studies.

\begin{tabular}{ccc}
\hline Configuration & Optimal Solar Multiple & $\begin{array}{c}\text { LCOE Conservative CSP, } \\
\text { USD/MWh }\end{array}$ \\
\hline $\begin{array}{ccc}\text { CSP without restriction } \\
\text { Night CSP in winter }\end{array}$ & 1.7 & 83.3 \\
$\begin{array}{c}\text { CSP supplement PV in } \\
\text { summer and without } \\
\text { restriction in winter } \\
\text { Night CSP }\end{array}$ & 1.5 & 112.7 \\
\hline
\end{tabular}

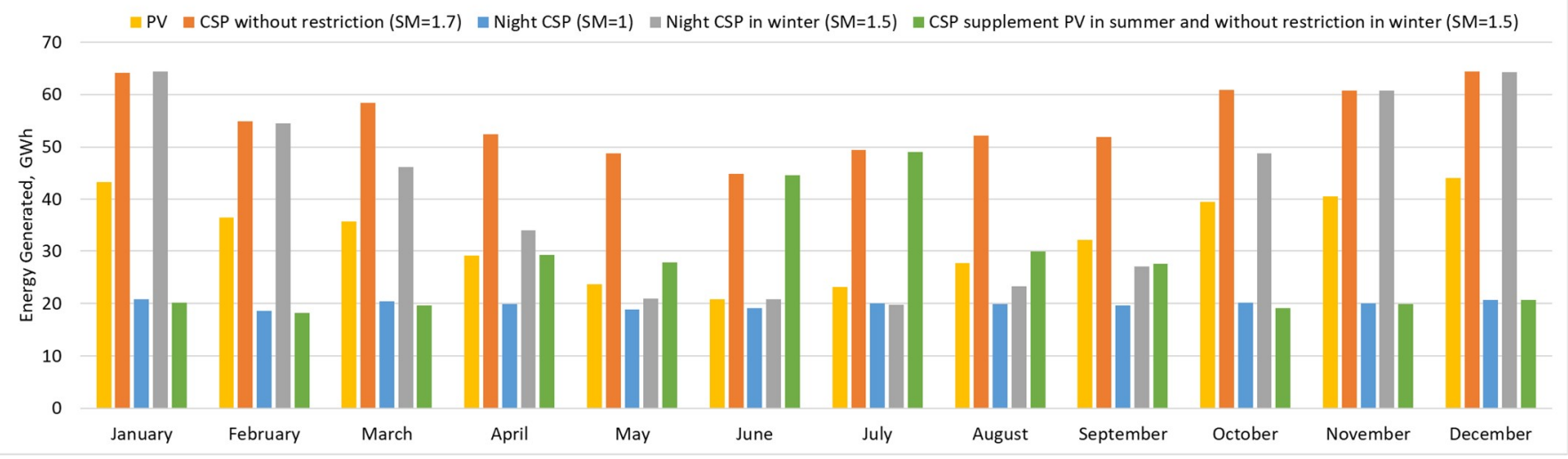

Figure 9. Annual energy generation for each plant according to the month of the year with different configurations. (CSP with 6 h of storage).

\subsection{Economic Analysis}

To perform an economic analysis based on the Levelized Cost of Energy (LCOE) of the different configurations of the CSP plant based on the generation profile, the technical parameters that affect the operation of solar plants were examined, such as the annual degradation rate and useful life for each, which are shown in Table 8 [10,11,45]. 
Table 8. Technical parameters for the economic evaluation of the hybrid plant.

\begin{tabular}{ccc}
\hline Parameter & Value & Reference \\
\hline & Lifetime & \\
\hline Lifetime of CSP systems & 40 years & {$[11]$} \\
Lifetime of PV Systems & 25 years & {$[10]$} \\
\hline & Degradation Rate & {$[46]$} \\
\hline CSP degradation rate & $0.2 \% /$ year & {$[46]$} \\
PV degradation rate & $0.6 \% /$ year & \\
\hline & Economic Rate & {$[45]$} \\
\hline Annual interest rate & $7 \%$ & \\
Inflation rate & $0 \%$ &
\end{tabular}

The cost structure for the LCOE analysis is shown in Table 9. For the photovoltaic plant, the cost structure reported by the CNE was used. However, the resulting LCOE is 45 USD/MWh, which is far from what was observed in the 2017/01 tender in Chile [46], among other news and publications regarding cost reductions of this technology [47]. For this reason, it is calculated that the investment cost for a photovoltaic plant with these characteristics is $713 \mathrm{USD} / \mathrm{kW}$ to obtain an LCOE close to $30 \mathrm{USD} / \mathrm{MWh}$ for the PV plant. The cost of investment and operation, maintenance, and administration of the electrical substation and the transmission line were chosen according to the voltage level of the substation closest to the location of the $110 \mathrm{kV}$ project according to the ones examined in the plan of 2019 expansion of the CNE [48]. The cost structure of the CSP plant is the one described in the work by Hernández et al. [41] that takes into account human resources, water consumption for cleaning the heliostat field, and consumption of the power cycle, among others, shown in Table 9 as OPEX CSP. The cost structure is built on the base case design, so for the following cases studied to obtain the LCOE, the percentage correction is applied as per the results obtained with SAM.

With the parameters in Tables 9 and 10, the configuration that minimizes the LCOE corresponds to the hybrid plant of PV plus unrestricted CSP plant, with a cost of $53 \mathrm{USD} / \mathrm{MWh}$. A close second best is $56 \mathrm{USD} / \mathrm{MWh}$ from the configuration of a PV plant together with a CSP plant with winter operation restrictions that move the dispatch from daylight to night. On the other hand, the configuration that obtained the highest LCOE within the cases studied is the hybrid plant that combines a PV plant with a daytime restricted CSP plant. Table 10 shows the details of the economic results for the CSP plant with $13 \mathrm{~h}$ of storage.

Table 9. Cost distribution for economic evaluation. MMUSD: Millions of dollars.

\begin{tabular}{cc}
\hline Parameter & Value \\
\hline CAPEX CSP Plant (130 MWe) & $3.25 \mathrm{MMUSD} / \mathrm{MWe}$ \\
CAPEX PV Plant (150 MWe) & $0.713 \mathrm{MMUSD} / \mathrm{MWe}$ \\
CAPEX Substation $110 \mathrm{kV}$ & $4.9 \mathrm{MMUSD}$ \\
CAPEX Transmission $110 \mathrm{kV}$ & $1.8 \mathrm{MMUSD}$ \\
OPEX Substation $110 \mathrm{kV}$ & $0.079 \mathrm{MMUSD} /$ year \\
OPEX Transmission $110 \mathrm{kV}$ & $0.016 \mathrm{MMUSD} /$ year \\
OPEX CSP & $5 \mathrm{MMUSD} /$ year \\
Variable Cost Operational CSP & $3.5 \mathrm{USD} / \mathrm{MWe}$ \\
Fixed OPEX CSP & $7.72 \mathrm{MMUSD} /$ year \\
Fixed OPEX PV & $1.6 \mathrm{MMUSD}$ \\
\hline
\end{tabular}


Table 10. Economic results for the CSP plant with $13 \mathrm{~h}$ of storage.

\begin{tabular}{ccccc}
\hline \multirow{2}{*}{ Plant Configuration } & \multirow{2}{*}{ Solar Multiple } & \multicolumn{3}{c}{ LCOE Plant, USD/MWh } \\
\cline { 3 - 5 } & & Hybrid & CSP & PV \\
\hline PV + CSP without restriction & 2.0 & 52.59 & 62.72 & 30.45 \\
PV + Night CSP & 1.5 & 70.63 & 98.00 & 30.45 \\
PV + Night CSP in winter & 2.0 & 55.61 & 68.06 & 30.45 \\
PV + CSP supplement PV in summer & 1.7 & 63.45 & 83.56 & 30.45 \\
and without restriction in winter & & & \\
\hline
\end{tabular}

The results for the case of a CSP plant with $6 \mathrm{~h}$ of storage are presented in Table 11. The table shows the variation of the LCOE with respect to the results obtained with SAM for the same configuration with $13 \mathrm{~h}$ of storage.

Table 11. Economic results for the CSP plant with $6 \mathrm{~h}$ of storage.

\begin{tabular}{ccccc}
\hline Configuration & $\begin{array}{c}\text { Solar Multiple } \\
\text { Optimal for 6 h, } \\
(-)\end{array}$ & $\begin{array}{c}\text { LCOE SAM 6 h } \\
\text { (USD/MWh) }\end{array}$ & $\begin{array}{c}\text { SAM 13 h } \\
\text { (USD/MWh) }\end{array}$ & $\boldsymbol{\Delta}$ SAM 6/SAM 13 h \\
\hline CSP without restriction & 1.7 & 83.3 & 88.3 & $-6 \%$ \\
Night CSP & 1.0 & 225.5 & 132.8 & $+70 \%$ \\
Night CSP in winter & 1.5 & 112.7 & 92.2 & $+22 \%$ \\
CSP supplement PV in summer & 1.5 & 153.7 & 118.1 & $+30 \%$ \\
and without restriction in winter & & & \\
\hline
\end{tabular}

\subsection{Case of a Gas Plant}

In recent years, the energy generation of gas plants in Chile has been gradually decreasing due to the diversification of the energy matrix. The Chilean system operator in the operation projection for the next five years observes that under a medium hydrology scenario, only $60 \%$ of all-natural gas plants will generate energy. The plants with the highest contributions are Mejillones, Nueva Renca, San Isidro, and Tocopilla, which have an annual plant factor range between 3\% and 85\% for the period between 2019 and 2024, with an average of $30 \%$.

Figure 10 presents the LCOE of a combined-cycle natural gas thermal plant with a capacity of $225 \mathrm{MW}$ and a useful life of 30 years [28]. For a plant of this type, the cost structure reported by the CNE in the generation technology costs report [27] was considered, which is shown in Table 12.

Table 12. The cost structure for gas combined cycle technology.

\begin{tabular}{cc}
\hline Items & Value \\
\hline CAPEX & 0.898 MMUSD/MWe \\
Non-fuel Variable Cost & 3.5 USD/MWh \\
Fixed Cost & $1 \%$ CAPEX \\
\hline
\end{tabular}

Figure 10 shows how the LCOE varies as a function of the plant factor, which has a wide range due to the operation characteristics of this type of power plant in the Chilean energy grid. The cost of the main input, in this case the price of the natural gas, is strongly influenced by the price of imports, by the price of crude oil, and the euro-dollar relationship. 


\begin{tabular}{|c|c|c|c|c|c|c|c|c|c|c|}
\hline \multirow{2}{*}{\multicolumn{2}{|c|}{$\begin{array}{c}\text { LCOE, } \\
\text { USD/MWh }\end{array}$}} & \multicolumn{9}{|c|}{ Plant Factor, \% } \\
\hline & & \multirow{2}{*}{$\frac{45}{96}$} & \multirow{2}{*}{$\begin{array}{l}50 \\
94\end{array}$} & \multirow{2}{*}{$\begin{array}{l}55 \\
92\end{array}$} & \multirow{2}{*}{$\begin{array}{l}60 \\
91\end{array}$} & \multirow{2}{*}{$\begin{array}{l}65 \\
90\end{array}$} & \multirow{2}{*}{$\begin{array}{l}70 \\
89\end{array}$} & \multirow{2}{*}{$\begin{array}{l}75 \\
88\end{array}$} & \multirow{2}{*}{$\begin{array}{l}80 \\
87\end{array}$} & \multirow{2}{*}{$\frac{85}{86}$} \\
\hline \multirow{9}{*}{ 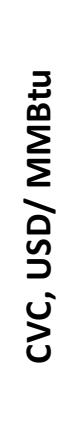 } & 2 & & & & & & & & & \\
\hline & 3 & 132 & 130 & 128 & 127 & 126 & 125 & 124 & 123 & 122 \\
\hline & 4 & 168 & 166 & 164 & 163 & 162 & 161 & 160 & 159 & 158 \\
\hline & 5 & 204 & 202 & 200 & 199 & 198 & 197 & 196 & 195 & 194 \\
\hline & 6 & 240 & 238 & 236 & 235 & 234 & 233 & 232 & 231 & 230 \\
\hline & 7 & 276 & 274 & 272 & 271 & 270 & 269 & 268 & 267 & 266 \\
\hline & 8 & 312 & 310 & 308 & 307 & 306 & 305 & 304 & 303 & 302 \\
\hline & 9 & 348 & 346 & 344 & 343 & 342 & 341 & 340 & 339 & 338 \\
\hline & 10 & 384 & 382 & 380 & 379 & 377 & 376 & 376 & 375 & 374 \\
\hline
\end{tabular}

Figure 10. LCOE of a gas plant according to plant factor and variable fuel cost (CVC) in a range of 72 and 359 USD/MWh. The color scale highlights the lowest LCOE in green and the highest LCOE in red.

From Figure 10 it can be seen that as the plant factor increases and the price of gas decreases, the LCOE of the gas-fired plant decreases, reaching a minimum price of 86.4 USD/MWh for a plant factor of $85 \%$ and a CVC of $2.0 \mathrm{USD} / \mathrm{MMBtu}$; whereas if the price of gas is kept at 2.0 USD/MMBtu (72 USD/MWh) and the plant factor decreases to $45 \%$, there is an LCOE of $96.1 \mathrm{USD} / \mathrm{MWh}$. In all the other cases mentioned here, the LCOE of the thermal plant exceeds $100 \mathrm{USD} / \mathrm{MWh}$.

\section{Discussion}

From the results obtained, it can be observed that the LCOE of the hybrid plant in any of the configurations studied here is more competitive than the best case studied for the thermoelectric gas plants (with plant factor of $85 \%$ and a variable fuel cost $(\mathrm{CVC})$ of 2.0USD/MMBtu).

On the other hand, when analyzing the results of the CSP plant independent of the $\mathrm{PV}$ plant, it is observed that a plant with $6 \mathrm{~h}$ of storage instead of $13 \mathrm{~h}$ with the proposed characteristics is more convenient only in the case of unrestricted operation, since LCOE decreases. For all other cases, LCOE increases.

When comparing the LCOE of both plants with respect to what is stated in the literature (see Table 13, [49]) it is observed that in the case of gas plants it is higher than the references because the plant factor in the Chilean electricity market is much lower for this technology. In the case of tower concentration technology, the LCOE of the CSP in all the cases presented here is lower, becoming 50\% lower with respect to the lower range of the reference LCOE. However, based on the current conditions of the Chilean electricity grid, the most realistic case corresponds to the summer-restricted one as there is a high local installed capacity of photovoltaic plants in the north of Chile and transmission restrictions; in the summer there would be curtailment so the plant could not produce electricity in sunny hours.

Table 13. LCOE reference for the technologies studied [49].

\begin{tabular}{cc}
\hline Plant & LCOE, USD/MWh \\
\hline Gas Combined Cycle & $44-68$ \\
Solar PV-Crys & $36-44$ \\
STP with Storage & $126-156$ \\
\hline
\end{tabular}

Based on all the results and the aforementioned economic and operational analyses, below are four points of view that should be taken into account for the operation of the Chilean electricity market with CSP technologies and natural gas technologies. 


\subsection{Flexibility}

Both technologies are very flexible. Solar thermal plants are a synchronous generation technology, with the ability to adjust their generation profile, providing stability, manageability and flexibility to the electricity grid without emitting greenhouse gases, while plants based on natural gas are intensive pollutants.

Solar thermal plants are designed as a stable power source and are independent of the instantaneous variability of the solar resource, making them continuous renewable energy technologies that are an excellent complement to variable renewables. STP technology has the characteristic of having starting times that range between 57 and $66 \mathrm{~min}$ to reach an output power of $100 \%$, less than the 15 min of open cycle gas turbine but slightly greater than combined cycle setups [50].

As already seen with the different configurations of CSP plants, these can play a role from a "peaker" installation to a "base load" depending on design, with ramps equal to or better than traditional thermal plants. While thermal storage, of daily replacement, has applications in different periods of time, mainly medium and long duration.

It is important to rethink the structuring of the future Chilean electricity market by prioritizing an intelligent operation taking advantage of the benefits and qualities of each technology. In this context, it is important that electricity markets are designed in such a way that energy sales are balanced with income from the provision of ancillary services. As the adoption of variable renewable energies increases, it becomes very important to use the flexible resources of the electrical system and compensate them according to the provision of said flexibility characterized based on specifically defined products to be traded in the market, such as different types of primary, secondary and tertiary reserves. For this, said products must be properly defined to balance the supply of said products with the needs of the system; in particular, if the definition is too narrow, there could be few suppliers, for example, some excessively fast reservation types. This should also define the compensations for providing services and the penalties in the event that a supplier cannot provide the promised service.

All these aspects are currently being discussed in the Flexibility Strategy of the Ministry of Energy [51], where the results of this work can pose an important contribution to the discussion from the economic point of view and related market rules.

\subsection{Reliability}

CSP technologies are reliable as they use proven technology from steam plants [52], which has existed for over 100 years, which together with storage, provide the dispatchability and reliability capabilities of CSP plants.

Some typical failures in CSP plants are the breakdown of mirrors and, less commonly, mechanisms in heliostats and the replacement of some parts of the receiver. Advances in the design and development of materials have made it possible to reduce the failure rate of the receivers, and although the malfunctioning of the mechanism in the heliostats continues to be an important fraction of the costs [53], it has become more manageable with programmed maintenance operations. Most importantly, this does not affect the supply security of a CSP plant but rather its maintenance cost structure.

On the other hand, thermal power plants have a disadvantage since they have a much higher failure rate than, for example, hydroelectric power plants [54], which causes more frequent exits from the electrical system (longer hours out of operation due to forced and scheduled availability), as well as a higher annual frequency of forced disconnections [55]. This, in turn, generates greater needs for primary reserve availability in the system, which has significant economic costs.

Another factor that influences the reliability of these plants is the availability of the input. In the case of natural gas plants, they must buy the fuel in a foreign market, so the price is strongly related to the economic principle of supply/demand, climatic conditions, dynamic conditions of production profiles, among others [39]. On the side of solar thermal plants, the solar resource is used, which is inexhaustible and renewable but variable. 
However, the Atacama Desert is characterized by high direct solar radiation and clear skies most of the year (90\% of the days have clear sky conditions) $[25,26]$.

In this context, an important question is how to design a capacity payment structure for each technology that adequately reflects the trade-offs associated with the reliability attributes and externalities of each technology.

\subsection{Economic Risk}

After analyzing the LCOE of the different technologies under certain assumptions, it is important to identify the risk in the input for these technologies. In the case of gas technologies, the price of the input is strongly influenced by market variables and climatic variables [37], in addition to the availability of the resource.

It is worth mentioning that within the current Chilean electricity market, there are restrictions on solar generation due to over-installation of this technology and/or due to the declaration of inflexible gas, which limits the sale of energy, causing a distortion in the market [56]. In this context, the more storage hours the CSP plant has, the lower the risk of curtailment and the greater access to selling energy under high spot prices.

Another economic risk is the incorporation of taxes on technologies that use fossil fuels and the correction to the green tax that currently operates in the Chilean electricity market so that it is included within the merit order of polluting plants.

\subsection{Descarbonization Process}

Chile has the goal of decarbonizing the energy grid by 2040 and being carbon neutral by 2050. In Chile, 78\% of the total emissions of greenhouse gases [8] come from the energy sector, whereas $45 \%$ correspond to the electrical subsector [7]. In this context, there is a high importance in both the electrification of non-electrical energy consumption and the transformation of the electrical matrix to a low or zero-emission matrix, which necessitate the incorporation of technologies that provide inertia in the energy network, short-circuit power, regulation sufficient voltage, flexibility, and complementary services to guarantee the safety and quality of the service [57].

The decarbonization process must deliver a reduction in polluting emissions, ensuring the continuity of the electricity service and at a reasonable cost for consumers, so competitiveness in the sector must be enhanced.

In particular, Chile has an ambitious agenda of progressive closure of coal-fired plants, which will lead to a complete shutdown by 2040. Let us remember that as of 2020, coal represents approximately $40 \%$ [7] of electrical energy generation and, furthermore, a very important integration of greater sources of photovoltaic and wind energy is expected, where both factors produce an important tension in the balance of the electrical network since flexibility sources will be closed at the same time as variable renewable energies that require flexible resources are incorporated. All this poses an excellent opportunity for dispatchable and flexible renewable energies, which will play a fundamental role in the decarbonization process.

\section{Conclusions}

Due to the challenges of decarbonizing Chile's energy matrix and the proposed goal of becoming carbon neutral by 2040, Chile is presented with the challenge of determining the best strategy by taking advantage of the benefits of each existing technology in the generation matrix. This requires studying the costs of the technologies and the benefits provided by each one in order to lower the general cost of electricity and to provide a robust baseload. Based on the LCOE calculations, the optimal configuration is the solar hybrid technology (PV plant and a CSP plant) with $13 \mathrm{~h}$ of storage without generation restrictions. This configuration has an LCOE of $53 \mathrm{USD} / \mathrm{MWh}$, followed by the solar hybrid plant with $13 \mathrm{~h}$ of storage with a nighttime generation profile during the winter. In contrast, the natural gas technology has an LCOE of $86 \mathrm{USD} / \mathrm{MWh}$ for a plant factor of $85 \%$ and a variable fuel cost of $2.0 \mathrm{USD} / \mathrm{MMBtu}$, which would be the best scenario for this 
technology (under the cases studied). On the other hand, CSP technology provides very similar systemic benefits, while avoiding important negative externalities, as compared to gas-fired plants, and is more cost-effective. In particular, CSP is highly flexible, has no emissions, and does not depend on external markets for fuel provisions. In all, it is a renewable energy that can help to lower the price of the grid and provide a flexible baseload electricity for Chile.

Author Contributions: Conceptualization, C.H.M., M.T.C.G. and A.S.; Formal analysis, A.S. and Á.G.L.; Investigation, C.H.M.; Methodology, A.S.; Project administration, M.T.C.G.; Supervision, M.T.C.G. and Á.G.L.; Writing—original draft, C.H.M.; Writing—review \& editing, M.T.C.G., A.S. and Á.G.L. All authors have read and agreed to the published version of the manuscript.

Funding: This work was supported in part by CORFO under project 13CEI2-21803.

Institutional Review Board Statement: Not applicable.

Informed Consent Statement: Not applicable.

Data Availability Statement: Not applicable.

Acknowledgments: Author C.H.M. acknowledges the generous financial support provided by CORFO under project 13CEI2-21803. The authors also thank Juan Marcelo Luengo for his valuable discussions.

Conflicts of Interest: The authors declare no conflict of interest.

\section{References}

1. Comité de Desarrollo de la Industria de la Energía Solar. Programa Energía Solar. Available online: https:/ /www.comitesolar.cl/ comite-solar/desierto-de-atacama/ (accessed on 8 October 2020).

2. Starke, A.R.; Cardemil, J.M.; Escobar, R.; Lemos, L.L.; Colle, S. Assessing the performance of Concentrated Solar Power plants in selected locations of Chile. In Proceedings of the ECOS, 28th International Conference on Efficiency, Cost, Optimization, Simulation and Environmental Impact of Energy Systems, Pau, France, 30 June-3 July 2015.

3. Comisión Nacional de Energía. Capacidad Instalada, Energía Abierta. 12 June 2020. Available online: http:/ /energiaabierta.cl/ visualizaciones/capacidad-instalada/ (accessed on 9 October 2020).

4. Ministerio de Energía-Gobierno de Chile. Ruta Energética: Liderando la modernización energética con sello ciudadano. 2018. Available online: https://energia.gob.cl/iniciativas/ruta-energetica-liderando-la-modernizacion-energetica-con-sellociudadano (accessed on 1 October 2020).

5. Séché Group Chile. El plan de descarbonización de Chile: Un doble desafío. 27 September 2019. Available online: https: / / www.sechegroup.cl/noticia/el-plan-de-descarbonizacion-de-chile-un-doble-desafio-2 (accessed on 12 June 2020).

6. Departamento de Mitigación e Inventario de Contaminantes Climáticos; División de Cambio Climático, Ministerio de Medio Ambiente. Informe de Inventario Nacional de Gases de Efecto Invernadero de Chile, Serie 1990-2013. Paulo Cornejo. 2017. Available online: https:/ /mma.gob.cl/wp-content/uploads/2017/12/2016_iin_cl.pdf (accessed on 1 October 2020).

7. Coordinador Eléctrico Nacional, CEN. Operación Real Horaria, CEN. Available online: https:/ / www.coordinador.cl/operacion/ graficos/operacion-real/ (accessed on 18 November 2020).

8. Ministerio de Energía. Plan de Descarbonización proceso histórico para Chile, Ministerio de Energía. Available online: https:// energia.gob.cl/noticias/aysen-del-general-carlos-ibanez-del-campo/plan-de-descarbonizacion-proceso-historico-para-chile (accessed on 17 July 2020).

9. Hernández Moro, J. Modelos de cálculo de Costes y Emisiones de CO2 Para la Electricidad Solar PV y CSP Según Diversos Escenarios (2010-2050). Ph.D. Thesis, Universidad Autónoma de Madrid, Madrid, Spain, 2013.

10. Moro, J.H.; Martínez-Duart, J.M. Analytical model for solar PV and CSP electricity costs: Present LCOE values and their future evolution. Renew. Sustain. Energy Rev. 2013, 20, 119-132. [CrossRef]

11. Parrado, C.; Marzo, A.; Fuentealba, E.; Fernández, A.G. 2050 LCOE improvement using new molten salts for thermal energy storage in CSP plants. Renewable Sustain. Energy Rev. 2016, 57, 505-514. [CrossRef]

12. Musi, R.; Grange, B.; Sgouridis, S.; Guedez, R.; Armstrong, P.; Slocum, A.; Calvet, N. Techno-economic analysis of concentrated solar power plants in terms of levelized cost of electricity. In AIP Conference Proceedings; American Institute of Physics: College Park, MD, USA, 2017; Volume 1850, p. 160018.

13. Hernández-Moro, J.; Martínez-Duart, J.M. CSP electricity cost evolution and grid parities based on the IEA road maps. Energy Policy 2012, 41, 184-192. [CrossRef]

14. Freeman, J.M.; DiOrio, N.A.; Blair, N.J.; Neises, T.W.; Wagner, M.J.; Gilman, P.; Janzou, S. System Advisor Model (SAM) General Description (Version 2017.9. 5) (No. NREL/TP-6A20-70414); National Renewable Energy Lab. (NREL): Golden, CO, USA, 2018.

15. Rashid, K. Design, Economics, and Real-Time Optimization of a Solar/Natural Gas Hybrid Power Plant. Ph.D. Thesis, The University of Utah, Salt Lake City, UT, USA, 2019. 
16. Xu, X.; Vignarooban, K.; Xu, B.; Hsu, K.; Kannan, A.M. Prospects and problems of concentrating solar power technologies for power generation in the desert regions. Renew. Sustain. Energy Rev. 2016, 53, 1106-1131. [CrossRef]

17. Aboelmaaref, M.M.; Zayed, M.E.; Zhao, J.; Li, W.; Askalany, A.A.; Ahmed, M.S.; Ali, E.S. Hybrid solar desalination systems driven by parabolic trough and parabolic dish CSP technologies: Technology categorization, thermodynamic performance and economical assessment. Energy Convers. Manag. 2020, 220, 113103. [CrossRef]

18. 4e, GIZ, Ministerio Federal de Medio Ambiente, Protección de la Naturaleza, Obras Públicas y Seguridad Nuclear de la República Federal de Alemania, Ministerio de Energía Gobierno de Chile. Sistema de Torre Solar-Estado y Perspectiva, Santiago de Chile. 2014. Available online: https://www.4echile.cl/publicaciones/sistemas-de-torre-solar/ (accessed on 10 July 2020).

19. Behar, O.; Khellaf, A.; Mohammedi, K. A review of studies on central receiver solar thermal power plants. Renew. Sustain. Energy Rev. 2013, 23, 12-39. [CrossRef]

20. Islam, M.T.; Huda, N.; Abdullah, A.B.; Saidur, R. A comprehensive review of state-of-the-art concentrating solar power (CSP). Renew. Sustain. Energy Rev. 2018, 91, 987-1018. [CrossRef]

21. Rashid, K.; Mohammadi, K.; Powell, K. Dynamic simulation and techno-economic analysis of a concentrated solar power (CSP) plant hybridized with both thermal energy storage and natural gas. J. Clean. Prod. 2020, 248, 119193. [CrossRef]

22. European Commission. Community Research, European Research on Concentrated Solar Thermal Energy; European Commission: Maastricht, The Netherlands, 2004.

23. Giacomozzi, F.G.; Comité Solar. Factores Críticos en Diseño Y Operación de Centrales CSP de Torre con Almacenamiento en Sales Fundidas en el Desierto de Atacama. Comité Solar: Santiago, Chile, 2017. Available online: http://www.comitesolar.cl/wpcontent/uploads/2018/08/Factores-cri\%CC\%81ticos-en-desarrollo-CSP-en-Chile-20170815.pdf (accessed on 10 July 2020).

24. Zurita, A.; Mata-Torres, C.; Cardemil, J.M.; Escobar, R.A. Assessment of time resolution impact on the modeling of a hybrid CSP-PV plant: A case of study in Chile. Solar Energy 2020, 202, 553-570. [CrossRef]

25. Castillejo-Cuberos, A.; Escobar, R. Understanding solar resource variability: An in-depth analysis, using Chile as a case of study. Renew. Sustain. Energy Rev. 2020, 120, 109664. [CrossRef]

26. Marzo, A.; Zarzalejo, L.F.; Ibarra, M.; Navarro, A.A.; Soto, G.; Ramirez, L.; Escobar, R.; Silva-Perez, M. Towards the Chilean solar thermal potential knowledge for solar power tower plants. In AIP Conference Proceedings; American Institute of Physics: College Park, MD, USA, 2018; Volume 2033, p. 170008.

27. Comisión Nacional de Energía. Informe de Costos de Tecnologías de Generación-Informe Anual; Comisión Nacional de Energía: Santiago, Chile, 2020.

28. Mahto, D.; Pal, S. Thermodynamics and thermo-economic analysis of simple combined cycle with inlet fogging. Appl. Therm. Eng. 2013, 51, 413-424. [CrossRef]

29. SolarPACES. Solar Power \& Chemical Energy Systems. 11 October 2017. Available online: https://www.solarpaces.org/cspcompetes-with-natural-gas-not-pv / (accessed on 10 July 2020).

30. PSR, Physicians For Social Responsibility, Concerned Health Professionals of NY, Heinrich BÖLL Stiftung, Compendio sobre hallazgos científicos, médicos y de los medios que demuestran los riesgos y daños del Fracking-Ex-tracción no convencional de gas y petróleo. December 2019. Available online: https://mx.boell.org/sites/default/files/2019-11/Fracking_libro_2019.pdf (accessed on 10 July 2020).

31. BBC News. Qué es el fracking y por qué genera tantas protestas, Alejandra Martins, BBC Mundo. 17 October 2013. Available online: https://www.bbc.com/mundo/noticias/2013/10/131017_ciencia_especial_fracking_abc_am (accessed on 10 October 2020).

32. International Energy Agency, IEA. Data and Statistics. Available online: https://www.iea.org/data-and-statistics?country= WORLD\&fuel=Energy\%20supply\&indicator=TPESbySource (accessed on 9 October 2020).

33. Chile Sustentable. Minuta Impuesto Verde. Available online: http://www.chilesustentable.net/wp-content/uploads/2019/04/ Minuta-Impuesto-Verde_chs.pdf (accessed on 13 July 2020).

34. Programa Chile Sustentable. Propuesta Ciudadana para el cambio, Impuesto verde para Fuentes Fijas en Chile, 29 January 2018. Available online: www.chilesustentable.net (accessed on 13 July 2020).

35. Diaz, G.; Muñoz, F.D.; Moreno, R. Equilibrium Analysis of a Tax on Carbon Emissions with Pass-through Restrictions and Side-payment Rules. Energy J. 2020, 41. [CrossRef]

36. Comisión Nacional de Energía. Informe técnico preliminar fijación de precios de nudo de corto plazo. June 2020. Available online: https:/ / www.cne.cl/wp-content/uploads/2020/06/ITP-PNCP-Jun20.pdf (accessed on 3 August 2020).

37. Libertex. Precio del Gas Natural. Available online: https:/ /ibertex.com/es/oil-gas/henry-hub-natural-gas (accessed on 10 July 2020).

38. S\&P Global Platts. Evaluación de precios de gas de Henry Hub. Available online: https://www.spglobal.com/platts/es/ourmethodology/price-assessments/natural-gas/henry-hub-natural-gas-price-assessments\# (accessed on 10 July 2020).

39. FRED Economic Data, “Economic Research," Federal Reserve Bank Of ST. Louis. Available online: https://fred.stlouisfed.org/ (accessed on 10 February 2021).

40. Energía Abierta. Catálogo estadísticas-Gas Natural. Available online: http://energiaabierta.cl/?s=gas+natural+\&t=api (accessed on 20 November 2020).

41. Hernández, C.; Barraza, R.; Saéz, A.; Ibarra, M.; Estay, D. Potential Map for the Installation of Concentrated Solar Power Towers in Chile. Energies 2020, 13, 2131. [CrossRef]

42. Ministerio de Energía. Explorador Solar,» Explorador Solar. Available online: http://www.minenergia.cl/exploradorsolar/ (accessed on 7 September 2020). 
43. Ju, X.; Xu, C.; Hu, Y.; Han, X.; Wei, G.; Du, X. A review on the development of photovoltaic/concentrated solar power (PV-CSP) hybrid systems. Solar Energy Mater. Sol. Cells 2017, 161, 305-327. [CrossRef]

44. Sistema de Evaluación ambiental-SEA. Declaración de Impacto Ambiental Planta de Concentración Solar de Potencia Copiapo Solar. October 2014. Available online: https:/ / seia.sea.gob.cl/archivos/2014/10/16/DIA_PCSP_Copiapo_Solar_-_Capitulo_06 .pdf (accessed on 15 June 2020).

45. Petrollese, M.; Cocco, D. Optimal design of a hybrid CSP-PV plant for achieving the full dispatchability of solar energy power plants. Solar Enery 2016, 137, 477-489. [CrossRef]

46. Comisión Nacional de Energía-Juan Carlos Martina. Licitaciones de suministro en Chile 2017/01. May 2018. Available online: https://investchile.gob.cl/wp-content/uploads/2017/04/CNE-Licitaciones-Andre\%CC\%81s-Romero_Abr-17.pdf (accessed on 7 September 2020).

47. Bellini, E.; Magazine, P.V. Available online: https://www.pv-magazine.com/2020/04/30/lcoe-from-large-scale-pv-fell-4-to-50 -per-megawatt-hour-in-six-months / (accessed on 7 August 2020).

48. Comisión Nacional de Energía-CNE. Expansión de Transmisión. Available online: https://www.cne.cl/tarificacion/electrica/ expansion-de-transmision/ (accessed on 20 November 2020).

49. LAZARD. Lazard's Levelized Cost of Energy Analysis-Version 13.0. November 2019. Available online: https://www.lazard. com/media/451086/lazards-levelized-cost-of-energy-version-130-vf.pdf (accessed on 2 November 2020).

50. Gonzalez, C. Webinar ACSP 2020-Atributos y prestaciones de la tecnología CSP, de seminario CSP 2020-la respuesta a la estabilidad sustentable del sistema eléctrico de chile, Santiago de Chile. 19 November 2020. Available online: https://acsp.cl/20 20/11/27/ revive-los-detalles-del-seminario-csp-2020/ (accessed on 17 December 2020).

51. Ministerio de Energía. Ministerio de Energía. 8 September 2020. Available online: https:/ / energia.gob.cl/noticias/nacional/ estrategia-de-flexibilidad-para-el-sistema-electrico-nacional (accessed on 11 November 2020).

52. Fraunhofer Chile. Concentración Solar de Potencia: La mejor solución para Chile. 7 May 2019. Available online: https:// www.fraunhofer.cl/es/Prensa/news/cset-notices/concentracion-solar-de-potencia---la-mejor-solucion-para-chile-.html\#: \{\}: text=Las\%20plantas\%20CSP\%20son\%20confiables,f\%C3\%A1cilmente\%20valoradas $\% 20 y \% 20$ tambi $\%$ C3\%A9n $\% 20$ financiadas (accessed on 24 November 2020).

53. International Renewable Energy Agency-IRENA. The Power to Change: Solar and Wind Cost Reduction Potential to 2025. June 2016. Available online: https:/ / www.irena.org/publications/2016/Jun/The-Power-to-Change-Solar-and-Wind-Cost-ReductionPotential-to-2025\#: \{\}:text=With\%20the\%20right\%20policies\%20in,Renewable\%20Energy\%20Agency\%20(IRENA) (accessed on 2 November 2020).

54. Casar, J.M.; Navarro, A. Informe Final-Centrales Termoeléctricas, Mercados e implicancias, Curso: Mercado Eléctricos. Available online: https:/ / hrudnick.sitios.ing.uc.cl/alumno03/thermo/Web_mercados.htm (accessed on 25 November 2020).

55. Coordinador Eléctrico Nacional (CEN). Documentos de Mercado, Indices de desempeño. 30 October $2020 . \quad$ Available online: https://www.coordinador.cl/mercados/documentos/indices-de-desempeno/calidad-de-suministro-indices-deindisponibilidad/2020-calidad-de-suministro-indices-de-indisponibilidad/septiembre-2020-calidad-de-suministro-indicesde-indisponibilidad/ (accessed on 25 November 2020).

56. Energía Estratégica. Opinión: En todas partes se cuecen habas y es con gas inflexible. Available online: https://www. energiaestrategica.com/opinion-en-todas-partes-se-cuecen-habas-y-es-con-gas-inflexible/ (accessed on 17 December 2020).

57. Araneda, J.C. Planificación de transmisión Coordinador Eléctrico Nacional. In Proceedings of the de Seminario CSP 2020, Santiago, Chile, 19 November 2020; Available online: https:/ /acsp.cl/2020/11/27/revive-los-detalles-del-seminario-csp-2020 / (accessed on 17 December 2020). 